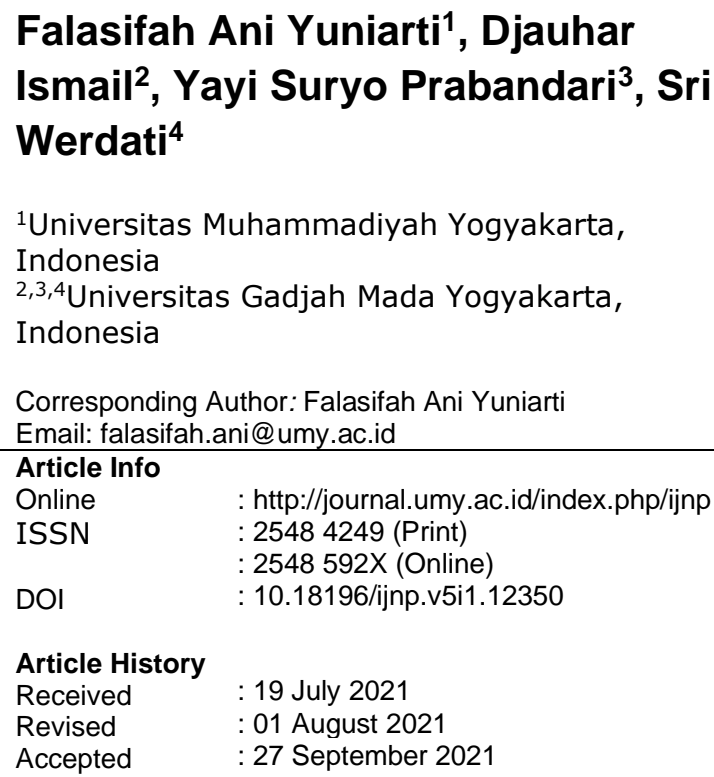

\section{Placing Priority on Faith in Providing a Foundation for Children to Face Puberty}

\begin{abstract}
Background: Children will experience puberty at the age of 915 years, influenced by several factors. Various changes require children to be ready to face them. Teachers carry out preparations, especially those who teach in elementary schools. Objective: This research is qualitative research that aims to explore the preparation made by teachers in preparing for puberty. A total of nine Islamic-based school teachers were interviewed at their schools.

Methods: In-depth interviews were conducted using structured open questions. The analysis employed Van Manen's method.

Result: This study raised three themes: the teacher's perception of student development, how the teacher prepares for puberty, and the problems faced in educating children to face puberty.

Conclusion: it is necessary to develop a model that can prepare children to enter puberty.
\end{abstract}

Keywords: Menarche; Pra Puberty; Puberty Preparation in Elementary School; Sex Education For School-Age Children

\section{INTRODUCTION}

Some children experience puberty at school age (612 years), mostly at 10-12 years old (Chomaria, 2012; Risman et al., 2016). According to Havighurst (Years), the developmental task theory of middle childhood states that children need to build healthy habits, learn the roles of men and women, build conscience, morality and values (Manning, 2002). Therefore, children of this age need attention, guidance and direction from adults such as their parents to develop properly and correctly (Santrock, 2011; Upton, 2012). Islam has provided a detailed explanation of the issue of sexuality. Islam has regulated what is accepted and not accepted in sexual behavior. In addition, decency and indecency are instincts that Allah created to regulate all aspects of life with the type and other aspects of life behavior such as dressing, eating and so on
(Halstead \& Reiss, 2004; Hastuti et al., 2016). Muslims in Indonesia are expected to implement sexual education for Muslim children based on religious rules and norms in Islam. It needs to be taught and emphasized to children to avoid violence, including sexual problems. Sexual education is important, and the role of parents, teachers and the environment is essential. Each has a role and it complements each other (Akers et al., 2011; Hastuti et al., 2016; Jackson et al., 2012; Lee et al., 2015; Leerlooijer et al., 2014; Protogerou \& Johnson, 2014).

Several obstacles were encountered in the implementation of sexual education for school-age children, namely inadequate parental knowledge, the assumption that sexual problems are taboo and dirty or sinful to talk about, and ignorance of how to 


\section{NUDRSEINANG \\ PRACTICES}

convey, and discrimination as a teenager accessing sexual health services (Grossman \& Charmaraman, 2016; Kamaljit et al., 2012; Khubchandani et al., 2014; Purwati \& Anjarwati, 2014; Tabatabaie, 2015; Weatherley et al., 2012). Inadequate parental knowledge occurs due to differences in knowledge, experience, cultural, religious and educational background (Allen et al., 2011). Those reasons prevent older people from providing inadequate information as children do not get enough information about sexual education. Consequently, children seek information from easily accessible sources or with their friends. They easily get information through their electronic devices. Friends can influence children positively or negatively. Children easily imitate what they see without realizing whether it is good. The aspects that stimulate sexual reactions such as sex films, soap operas, books and magazines with sexy pictures, temptations and stimulation from men and women, as well as direct observation of sexual behavior, will result in peaking or increasing sexual reactions and sexual maturity faster in children (Fathunaja, 2015; Rahmawati, 2015; Widanarti \& Nashori, 2015; Yusuf, 2015; Zahara \& Karyani, 2018). On the other hand, parents cannot completely filter out these negative influences. Therefore, active mediation is needed to build self-awareness and help children sort out whether the content is good or bad (Catherine et al., 2017). In addition, information obtained regarding reproductive health is also limited. Children who are not directed are likely to get the wrong information; thus, they form wrong perceptions. According to the Data and Information Center of the Indonesian Ministry of Health (Infodatin) regarding the Adolescent Reproductive Health Situation in 2013, data showed the percentage of pre-marital sex for adolescents aged 10-14 years increased from 2007 to 2012; in males, it increased from $3.7 \%$ to $4.5 \%$ while in females aged 15-19 years, pre-marital sexual activity decreased from $1.3 \%$ to $0.8 \%$. (Pusat Data dan Informasi Kementrian Kesehatan RI, 2015).

Efforts to raise children's awareness about sexuality issues can be carried out. Berman, Snyder, Kozier dan Erb (2008) suggested that health promotion is a habit motivated to enhance good standing and actualize potential health (Berman et al., 2008). Schools are one of the places where health promotion programs are implemented. Children spend years in school, and programs created in schools can be more focused and cost-effective (Berman et al., 2008). Some interventions related to sexual education have been carried out in primary school students in several studies (references). Winarti and colleagues (years) conducted a study in the fifth grade on providing health education with elementary school students' anxiety in facing menarche. The results showed a significant effect of providing health education on students' anxiety who faced menarche (Winarti et al., 2017). However, some children have experienced menstruation in the fourth grade of elementary school. The result from a private secondary Islamic school study triggered a question of elementary school children's knowledge of sexual health where puberty school children are more likely to occur (Lukmana \& Yuniarti, 2018). Thus, it is necessary to prepare beforehand to prepare children better when entering puberty. This study aims to explore the experiences of Islamic base elementary school teachers in preparing children for puberty.

\section{METHODS}

To explore the experiences of Islamic base Elementary school teachers in preparing their students, the researcher employed a qualitative study. Qualitative descriptive research explores the phenomena (Polite \& Beck, 2008). A semistructured interview method was used, and an interview guide included questions about their perception of puberty on children nowadays. The preparation needs to be made for children who are facing puberty, what they have done to prepare their children for puberty, what the students need to know in preparing themselves for puberty in accordance with Islamic teachings, how preparation for puberty is related to curriculum, and what should be given to children and how it will be given to prepare children to puberty.

Interviews were conducted with nine teachers currently teaching upper grades in three Muhammadiyah elementary schools in Yogyakarta. The teachers were homeroom teachers, science, religion, and sports teachers. The school was chosen with permission from Majelis Pendidikan Dasar dan Menengah (Primary and Secondary Education Board) of Muhammadiyah Yogyakarta; each school 
has two groups of level four and five. The head of the school sent the name of the teachers. Firstly, the researcher sent a bundle of information about the research to the potential participant, and then the researcher obtained the informed consent from the participants in two days. The researcher conducted interviews with prospective participants who were willing to become research participants. Data collection was carried out by in-depth interviews with 9 (nine) teachers for about an hour face to face in the sitting room of the schools. Two research assistants helped the researcher take notes and documentation during the interviews. All interviews were recorded using a SONY IC Recorder. After conducting the interview, the research assistant transferred the interview recordings into a conversational transcript form, using the $\mathrm{O}$ Transcribe application. After the transcript was made, the researcher double-checked by listening to the conversation and reading the transcript. It was done to minimize the possibility of a loss of information. The researcher only allowed the research assistant to transcribe the recorded interview and save the recordings files to protect participant identity.

Furthermore, this study was analyzed by Van Manen's method. It consisted of three methods: a holistic approach, selective approach, and detailed approach. Firstly, the researcher read the text in the holistic approach and captured its meaning. Secondly, in the selective approach, the researcher highlighted or pulled out statements or phrases that seemed essential to the experience under study. Finally, the researcher analyzed every sentence (Polite \& Beck, 2008). This research had received ethical approval from the ethics committee of the Faculty of Medicine and Health Sciences, University of Muhammadiyah Yogyakarta number 001/EPFKIK-UMY/I/2020.

\section{RESULT}

After the researchers read the interview transcripts and analyzed the data using Van Manen's method, the researchers set three emerging themes. These themes included the teacher's perception of student development, how the teacher prepared for puberty, and the problems faced in educating children to face puberty.

(see figure 1)
Figure 1 shows two sub-themes, namely physical development and social development. Teachers observed that their students developed faster than their time. Girls obtained their period earlier, even in fourth grade. Meanwhile, boys grew taller quickly. There were cases where children who were exposed to pornography had different views.

“...when streaming, sometimes cartoons appear... but when the boy and girl are close together, the two children have a different way of looking at them from their friends, who incidentally see the children as children. The child knows it from his eyes, he can see it, oh his eyes are eyes that..." (Participant 2)

Two themes can be raised from the social side: friendship with the opposite gender and gadgets. Regarding socializing with the opposite gender, the participant perceived that students were already embarrassed to play with the opposite gender, especially girls who have experienced menstruation. Those who got used to playing with their friends began to limit themselves after puberty. Some children have started to be attracted to the opposite gender; some claimed to have a boyfriend, as stated by one participant.

"There are some fifth graders who already have girlfriends...The emotion is that now there is such thing as dating. In my past, there was no such thing; for example, we were in the same class sitting with the boy, there was no one who made fun of it by saying 'hiiii hiiii', now, ihi ihi... Wow". (participant 3)

As for gadgets, some children already have cellphones. Teachers ask parents to postpone giving children gadgets as they are still not ready to be morally responsible for using them. However, parents have already given it. As a result, they do not freely control the use of gadgets.

"Due to cellphones, children sometimes are against their parents; they argue and can continue to be against them in the form of disobedience, and I see more or less the news spread outside has a negative impact." (participant 1)

Regarding the use of gadgets, children exposed to pornography have a different perspective, as one of the participants stated. 


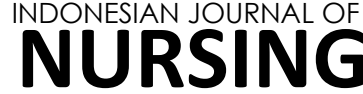 \\ PRACTICES}

"The child's behavior is more... what is it... from the way they look, for example, from the first glance they stare at each other, then the other students see, that is the way they think, na.." (participant 6)]

\section{How Teachers Prepare Children for Puberty}

Figure 2 shows the subtheme arising under the theme of how teachers prepare children for puberty. Those aspects included method, media and subject matter. Teachers used various methods to deliver material related to the preparation of puberty, for example, through the advice given at the beginning of the lesson or inserted during the lesson or using a certain moment. The teacher also held a girls' class on Fridays when the boys performed Friday prayers.

Teachers prepared their students for puberty in various ways. According to one participant, teachers alternated roles in interacting with students, sometimes as teachers, parents, friends, police, or judges. It is done so that students captured the value presented. Teachers frequently paid attention to their students and advised them through roles based on the circumstances.

\section{(see figure 2)}

The teacher prioritized lessons about faith in Allah SWT, supervision from Allah, a description of the grave, and accountability for all actions on the last day. One participant stated,

"... I have not focused on material changes to his body or anything else, I pay attention to aspects of the mindset, so what is it, that there is a God who watches over you, maybe that is the best, so it is more divine if I do not waste it" (participant 2)

"...For me, the first is faith. I emphasize faith... well, when we have faith, we will talk about puberty and its dangers.. it will be better." (participant 5)

In addition, in terms of faith lessons, the teacher also conveys lessons about the association between men and women and physical changes during puberty

"...It seems that there is a lesson, but I was more concerned about the separation, so I was more careful. Covering the aurat of course, then the association between men and women is also carried out, yes, some knowledge about maturity, related to being an adult and how to behave, has been conveyed, especially for women." (participant 1 )

These materials are implemented on various occasions and in several ways. For example, there are cases outside of school that are interesting to discuss during lessons and girls' classes. Meanwhile, the methods used are, for example, by showing related programs from YouTube, giving a kind of trauma to children, and scolding children for violating principles. The trauma in question provides an experience difficult for children to forget.

Some of the lessons are contained in the curriculum, for example, physical changes during puberty, which are given in sixth grade, about respecting others, attitudes towards the opposite gender, body parts that may and may not be touched and problems with taharah (cleanliness), tayammum and water are given since students are in the first grade.

“...From grade one to grade six, I also taught students about body parts, basically about body parts that should not be touched..." (participant 5)

"...Yes, first grade, second grade, because we introduce ablution, tayamum, and najis including moderate and heavy level. Furthermore, in terms of the taharah level and purification, there is a level of using water, which started in first grade. there is..." (participant 1)

In addition to the students, a meeting was also held with parents. The meeting is held during academic report distribution day or regular meetings filled with parenting lessons. On that occasion, the teacher again equalizes the perception of parents' responsibility for children's education, where the parents will bear the child's sins if the child is not well-educated according to God's command.

$" . .$. here every month there is a recitation on Sunday morning, after that, a consultation is held with the student's guardian ..." (participant 4)

\section{Problems encountered in educating children to face puberty}

There are at least three issues of educating children to face puberty, as shown in figure 3 . The issues 
come from the internal and external parties. The problems include an unclear explanation about puberty, parents who lack synergy with the school, unclear materials, and a less supportive environment and friends.

The unclear authority in providing material about puberty may be due to the lack of teacher coordination in this issue. Thus, the material is given based on the initiative of the teacher.

\section{(see figure 3)}

Sometimes, some parents are not in line with the teacher in educating their children. Parents do not carry out what has been conveyed in the teacher and parent meetings. The teacher knows this issue from the student's confession, like the problem of cell phones, which according to the teacher, is not yet time for students to have since they do not have the responsibility to use them. Some parents give it as a gift, and that the ownership is in the hands of the child, and parents will find it difficult to control.

"...how to use sanitary napkins or something like that, you know, it has never been taught, so I do not know whose authority it is, teacher's authority I think, and sports teachers or maybe parents should tell me how to use sanitary napkins properly" (participant 8)

"...as I am a religious teacher, I have to give this because it is related to purification, about menstruation, what to do after menstruation, etc. If the curriculum does not exist and the teacher does not explain it themselves, they will be surprised in grade 6 about what menstruation is, so they do not know what it was like..." (participant 1)

Furthermore, other influences come from friends and the environment. Of course, the scope of teacher supervision cannot extend to the environment outside the school and children's playmates outside of school. Bad influences often occur due to friends outside this school.

\section{DISCUSSION}

Based on the results as shown in figure 1, 2 and 3, three themes emerged from this study: teachers' perception of student development, teachers' preparation for students' puberty, and the problems encountered in educating children to face puberty.
Two sub-themes were raised regarding the development of children observed by the teacher, namely physical and social development. The teacher stated that girls experienced earlier menarche and boys experienced faster height gain. Puberty for boys and girls in developed countries has decreased since the 1800s. The age difference of puberty is about three years from the 2000s. It occurs due to changes in social structure, improved nutrition and increased health standards. Furthermore, life stress also plays a role in aging (Bellis et al., 2006). This decrease is not related to gestational age at birth. Menarche in children born prematurely occurs later than in those born normally (Hui et al., 2012). However, social puberty is not as accelerated as physical puberty. The age of social maturity of children does not correlate with physical maturity. Thus, various problems can arise, such as physical problems, academic problems, difficulties in communicating with friends, parents and family, high-risk behavior, early pregnancy, and so on (Mostofi et al., 2018).

Meanwhile, in terms of the problem of height, Indonesia has experienced stunting for a long time. This stunting condition causes childrens' low height in their age. Stunting probably occurred after the forced cultivation program carried out by the Dutch colonial. The land they cultivated for family needs was reduced in size, which also impacted the health of family members. It leads to a more serious problem during Japanese colonialism. After Indonesia's independence, stunting remains a major problem in children health under five. During the New Order regime, health management was more organized. Meanwhile, during the administration of President Susilo Bambang Yudhoyono, the stunting problem was brought back for improvement. During the administration of President Jokowi, stunting was still a priority in the health sector, resulting in a decline of up to $30 \%$ (Siswanto, 2019). Thus, it is possible that the government program in the health sector prioritizes stunting, improvements in the economy, and increasingly fulfilled nutrition, causing children's height to increase faster.

The teachers' statement about the social development of their students was that there was an interest in the opposite gender, that the students hesitate to play with the opposite gender and possession of gadgets. In school-age, children are already familiar with the world outside the family. Children have been hanging out with other children 


\section{NURSING \\ PRACTICES}

and interacting with the opposite gender. Some children have started to be interested in each other; some even have a boyfriend. According to Sullivan, having a romantic relationship is an important developmental stage in a child's life and a change that a child will experience (Chomaria, 2012; Ivanova \& Veenstra, 2012; Risman et al., 2016). However, Islam teaches that attraction feeling towards the opposite gender is controlled by lowering the gaze, controlling hesitancy, teaching what is allowed and not allowed, avoiding mixing of men and women, etc. Therefore, it is natural for children to feel hesitant when hanging out with the opposite gender. This trait will keep them from transgressing as they feel that Allah is always watching over them (Chomaria, 2012).

The last thing the teacher stated was gadgets, especially smartphones. Children easily access the information only in a safe hand. The problem is that the accessible information is random, regardless of the appropriateness (Chomaria, 2012; Shin et al., 2019). Therefore, children need to be equipped with limiting views and curiosity and saying "no" to pornographic things.

The teachers prepare their students to face puberty in various ways, namely by giving advice, doing various roles, and carrying out girlhood classes. At the same time, the media frequently used is video. What is conveyed to children concerns faith in Allah, the relationship between men and women and physical changes. The teacher's experience in interaction with the students makes them understand their students and influences their ways of promoting sexual health and preparing them for puberty. Ulwan (2017) mentioned that advice given to children at the right time would hit and be easier for children to understand. Teachers use occasions to advise their students, such as caring for the children when they have problems, one-on-one communication, and discussing problem-solving. There was an incident when the students did not memorize the prayer spell given by the teacher weeks before. It made the teacher unpleasant. The teacher used this chance to admonish and advise them about the importance of memorizing the prayers spellings, which directly affected the students. Since then, the students have been able to memorize the spell. Abdullah Nashih Ulwan already mentioned the advice method. He stated that sincere and influential advice would significantly impact if delivered with a clean heart and wise mind. These pieces of advice can be conveyed in several methods, namely: telling stories, dialogues and asking questions, starting with an oath in the name of Allah, inserting jokes in conveying advice, arranging advice to avoid boredom, giving examples with hand demonstrations, with the media of images, with practice and take advantage of the momentum, diverting to the important things and showing what is forbidden (Ulwan, 2017). Teachers employed only some methods, such as telling stories, telling jokes, giving examples, taking momentum, and showing what needs to do and not to do.

Meanwhile, the material taught emphasizes faith in God, the interaction of men and women and physical changes. Teachers mentioned that faith in God is a basic thing emphasized to children. If the child already has a strong faith in Allah, it will be easier to follow what is ordered and prohibited. This statement was also mentioned by Ulwan (2017) that teachers and parents should prioritize the education of faith in Allah SWT. The cultivation of faith in Allah SWT is carried out by contemplating and thinking about the creation of the heavens and the earth, which is carried out from sensing rational things, from small parts to whole things, and from simple to complex ones. It makes children have a strong foundation of faith based on evidence and satisfactory arguments (Ulwan, 2017).

Signs in a relationship need to be given to children as they will experience feelings of attraction and ripple when close to the opposite gender. These signs are given to understand the relationship in a healthy manner (Chomaria, 2012; Madani, 2003).

However, some problems arise both from internal and external parties of the school. The internal problems include the lack of coordination between teachers and the material hardly understood by students. Meanwhile, external problems include parents, friends and the environment. The children are the responsibility of the teacher during school time. However, when they return home, the responsibility goes back to their parents. Furthermore, when children go outside, they will get 
a bad influence from their friends or environment if they do not have strong provisions. Therefore, children need to be given a foundation that can counteract the negative impacts of the environment. This provision can be instilled by parents and teachers. Thus, it is necessary to have good communication and relationships between parents and teachers in this case. What is taught in school can be applied at home and vice versa. Moreover, if there is a problem with the child, both can work together to solve it, not blaming each other (Chatib, 2016). It was revealed in interviews through the teacher's statement that sometimes parents were not in tune with school education which caused children to behave inappropriately.

Teachers need coordination in providing material to students about who teaches and what needs to be taught. There is nothing wrong with repetition as it will strengthen students' understanding. In terms of external problems, the teacher cannot control them. In Arabian states, except for Tunisia and Iran, there are very few programs addressing young people's sexual and reproductive health. Curricula about the topics were rare. If there were few, the teachers frequently skipped over it (DeJong et al., 2005). Meanwhile, in Malaysia, the problem was almost similar in Arabic states. Sex and reproductive education were prepared inadequately by teachers, such as instruction and teaching materials and a lack of school and community support (Kamrani \& Yahya, 2016). It is likely that sex and reproductive education are still challenging to teach in many countries. Therefore, the program is needed to prepare their puberty, especially for school-age children. The model contains guidance on sex education based on child development, relationships with others, including etiquette (adab), and faith to Allah SWT.

This study was conducted in three elementary schools with Islamic backgrounds. It only conducted interviews with nine teachers. However, the study results can be used to determine the next steps. The results of this study indicated that the coordination between teachers was still limited; thus, the authority of each teacher in providing the material was unclear. In addition, it is necessary to involve parents in preparing children for puberty and that a harmonious relationship between teachers and parents is developed. Furthermore, the researcher proposes a guidebook on preparation for puberty that teachers, parents and children can use to facilitate the delivery of material and as learning material for students.

\section{CONCLUSION}

Teachers prepared students for puberty with various methods, media, and materials. Coordination and cooperation between parents and teachers were needed to prepare children to enter puberty. Further researchers can develop media that can be used as references for teachers, parents, and children. Besides, further research is also suggested to carry out by using quantitative and qualitative research methods with larger and wider samples or participants to generalize this research.

\section{ACKNOWLEDGEMENT}

This article was presented at ICONURS 2020 in ICOSI of Universitas Muhammadiyah Yogyakarta. This research was conducted with financial assistance from BPPDN, LP3M UMY, and the Faculty of Medicine and Health Sciences UMY. The authors would like to thank the Education Council for the Muhammadiyah Regional Management of Yogyakarta City, the school administrators, teachers, and students where the research was conducted, and the assistants in this research.

\section{REFERENCES}

Akers, A. Y., Holland, C. L., \& Bost, J. (2011). Interventions to Improve Parental Communication About Sex: A Systematic Review. Pediatrics, 127(3), 494-510. https://doi.org/10.1542/peds.2010-2194

Allen, K. R., Kaestle, C. E., \& Goldberg, A. E. (2011). More Than Just a Punctuation Mark: How Boys and Young Men Learn About Menstruation. https://doi.org/10.1177/0192513X10371609

Bellis, M. A., Downing, J., \& Ashton, J. R. (2006). Adults at 12 ? Trends in puberty and their public health consequences. In Journal of Epidemiology and Community Health 60(11). https://www.jstor.org/stable/40665356

Berman, A., Snyder, S. J., Kozier, B., \& Erb, G. (2008). Fundamental of Nursing: Concepts, Process and Practive (8th ed.). Pearson Education, Inc.

Catherine, O., Pandia, W. S. S., \& Pristinella, D. (2017). Exploring Parental Mediation of Elementary School-Aged Children's Gadget Use. In B. N. Setiadi (Ed.), Urban Living and Multicultural Cities in Asia: From Colonial Past 


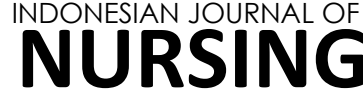 \\ PRACTICES}

to Global Future (pp. 134-145). Atma Jaya Catholic University Indonesia.

https://www.neliti.com/publications/217686

Lexploring-parental-mediation-of-

elementary-school-aged-childrens-gadgetuse

Chatib, M. (2016). Orang Tuanya Manusia (2nd ed.). PT Mizan Pustaka.

Chomaria, N. (2012). Pendidikan Seks Untuk Anak. Aqwam.

DeJong, J., Jawad, R., Mortagy, I., \& Shepard, B. (2005). The Sexual and Reproductive Health of Young People in the Arab Countries and Iran. Reproductive Health Matters, 13(25), 49-59.

https://dx.doi.org/10.1016/S09688080(05)25181-9

Fathunaja, A. (2015). Reorientasi Pendidikan Seks Terhadap Anak Usia Remaja Di Sekolah (Memadukan Sains dan Agama dalam Pembelajaran). Jurnal JPSD (Jurnal Pendidikan Sekolah Dasar), 1(1), 104-124.

Grossman, J. M., \& Charmaraman, L. (2016). Do as I Say, Not as I Did: How Parents Talk With Early Adolescents About Sex. https://doi.org/10.1177/0192513X13511955

Halstead, J. M., \& Reiss, M. (2004). Sex Education: Nilai dalam Pendidikan Seks bagi Remaja: dari Prinsip ke Praktek (N. H. Effedi (ed.); 1st ed.). Alenia Press.

Hastuti, L., Prabandari, Y. S., Ismail, D., \& Hakimi, M. (2016). Reproductive Health of Early Adolescents in the Islamic Perspective: A Qualitative Study in Indonesia. Journal of Islamic Studies and Culture, 4(1), 134-142. https://doi.org/10.15640/jisc.v4n1a16

Hui, L. L., Leung, G. M., Lam, T. H., \& Mary, C. (2012). Premature Birth and Age at Onset of Puberty. Schooling Source: Epidemiology, 23(3), 415-422. https://doi.org/10.1097/EDE.0b013e31824d $\underline{5 f d 0}$

Ivanova, K., \& Veenstra, R. (2012). Who Dates? The Effects of Temperament, Puberty, and Parenting on Early Adolescent Experience with Dating: The Trails Study. https://doi.org/10.1177/0272431610393246

Jackson, C., Geddes, R., Haw, S., \& Frank, J. (2012). Interventions to prevent substance use and risky sexual behaviour in young people: $\mathrm{A}$ systematic review. Addiction, 107(4), 733747.

https://doi.org/10.1111/i.13600443.2011.03751.x

Kamaljit, K., Balwinder, A., Gurmeet, K. S., \& Neki, N. S. (2012). Social beliefs and practices associated with menstrual hygiene among adolescent girls of Amritsar, Punjab, India. Journal International Medical Sciences Academy, 25(2), 69-70.

https://www.scopus.com/inward/record.url? eid=2-s2.0-

84864468628\&partnerlD=tZOtx3y1

Kamrani, A., M., \& Yahya, S. S. (2016). Bringing X, Y, $Z$ Generations Together to Facilitate SchoolBased Sexual and Reproductive Health Education. Global Journal of Health Science, 8(9), 132.

https://doi.org/10.5539/gjhs.v8n9p132

Khubchandani, J., Asalkar, M., \& Midha, I. (2014). Students' Perceptions and Doubts About Menstruation in Developing Countries: A Case Study From India. 15(3), 319-326. https://doi.org/10.1177/1524839914525175

Lee, Y. M., Florez, E., Tariman, J., McCarter, S., \& Riesche, L. (2015). Factors related to sexual behaviors and sexual education programs for Asian-American adolescents. Applied Nursing Research, 28(3), 222-228.

https://doi.org/10.1016/j.apnr.2015.04.015

Leerlooijer, J. N., Ruiter, R. A. C., Damayanti, R., Rijsdijk, L. E., Eiling, E., Bos, A. E. R., \& Kok, G. (2014). Psychosocial correlates of the motivation to abstain from sexual intercourse among Indonesian adolescents. Tropical Medicine and International Health, 19(1), 7482.

https://doi.org/10.1111/tmi.12217

Lukmana, C. I., \& Yuniarti, F. A. (2018). Gambaran tingkat pengetahuan kesehatan reproduksi remaja pada siswa SMP di Yogyakarta. IJNP (Indonesian Journal of Nursing Practices), 1(3), 115-123.

https://doi.org/10.18196/ijnp.1369

Madani, Y. (2003). Pendidikan Seks Untuk Anak dalam Islam (I). Pustaka Zahra.

Manning, M. L. (2002). Havighurst's Developmental Tasks, Young Adolescents, and Diversity. The Clearing House, 76(2), 75-78. 
Mostofi, N., Shamshiri, A. R., Shakibazadeh, E., \& Garmaroudi, G. (2018). Effectiveness of a sex education program for mothers of adolescent girls based on Health Belief Model on mothers' knowledge, attitude, and behaviour. Research Article Pediatric Dimensions, 3(4), 1-5. https://doi.org/10.15761/PD.1000180

Polite, D. F., \& Beck, C. T. (2008). Nursing Research: Generating and Assesing Evidence for Nursing Practice (8th ed.). Lippincott Williams \& Wilkins.

Protogerou, C., \& Johnson, B. T. (2014). Factors Underlying the Success of Behavioral HIVPrevention Interventions for Adolescents: A Meta-Review. AIDS and Behavior, 1847-1863. https://doi.org/10.1007/s10461-014-0807-y

Purwati, N., \& Anjarwati. (2014). The Relationship Between Teacher Attitudes of Sexual Education Towards Adolescents And The Implementation of Sexual Education At The State Of Junior High School (SMPN) 1 Pajangan Bantul 2013. May, 18-20.

Pusat Data dan Informasi Kementrian Kesehatan RI. (2015). Situasi Kesehatan Reproduksi Remaja. https://www.depkes.go.id/resources/downl oad/pusdatin/infodatin/infodatin reproduksi remaja-ed.pdf

Rahmawati, I. A. (2015). Hubungan Antara Spiritual Value Dengan Pengendalian Dorongan Seksual Pada Remaja Berbasis Perspektif Gender.

Risman, E., Madani, H. Al, \& Maisura, Y. (2016). Ensexclopedia: Tanya Jawab Masalah Pubertas \& Seksualitas Remaja. Yayasan Kita dan Buah Hati.

Santrock, J. W. (2011). Life-Span Development (Vol. 1). Erlangga.

Shin, H., Lee, J. M., \& Min, J. Y. (2019). Sexual knowledge, sexual attitudes, and perceptions and actualities of sex education among elementary school parents. Child Health Nursing Research, 25(3), 312-323. https://doi.org/10.4094/chnr.2019.25.3.312

Siswanto. (2019). Melacak Jejak Stunting dari Zaman Kolonial. Akurat.Co. https://akurat.co/melacak-jejak-stuntingdari-zaman-kolonial

Tabatabaie, A. (2015). Childhood and adolescent sexuality, Islam, and problematics of sex education: a call for re-examination. Sex Education, 15(3), 276-288. https://doi.org/10.1080/14681811.2015.100 $\underline{5836}$

Ulwan, D. A. N. (2017). Pendidikan Anak Dalam Islam (10th ed.). Penerbit Insan Kamil Solo.

Upton, P. (2012). Psikologi Perkembangan. Penerbit Erlangga.

Walker, J. L. (2001). A qualitative study of parents' experiences of providing sex education for their children: The implications for health education. Health Education Journal, 60, 132146.

https://doi.org/10.1177/0017896901060002 $\underline{05}$

Weatherley, R., Siti Hajar, A. B., Noralina, O., John, M., Preusser, N., \& Yong, M. (2012). Evaluation of a school-based sexual abuse prevention curriculum in Malaysia. Children and Youth Services Review, 34(1), 119-125. https://doi.org/10.1016/j.childyouth.2011.09 .009

Widanarti, M., \& Nashori, F. (2015). Pengaruh Pendidikan Seksual Islami Terhadap Sikap Permisif Terhadap Perilaku Seksual Pranikah Pada Remaja. Jurnal Psikologi "Mandiri," 1(2).

Winarti, A., Fatimah, F. S., \& Rizky, W. (2017). Pengaruh Pendidikan Kesehatan Terhadap Kecemasan Tentang Menarche pada Siswi Kelas V Sekolah Dasar. Jurnal Ners Dan Kebidanan Indonesia, 5(1), 51-57.

https://ejournal.almaata.ac.id/index.php/JN $\mathrm{KI} /$ article/view/360

Yusuf, M. (2015). Membangun Karakter Berbasis Pendidikan Spritualitas. Review Pendidikan Islam, 2(1), 136-164.

Zahara, E. U., \& Karyani, U. (2018). Kepribadian Remaja Pelaku Tindak Asusila. https://eprints.ums.ac.id/59799/1/Naskah Publikasi.pdf 


\section{NUNRSERING \\ PRACTICES}

Perception of teachers on the Development of Students

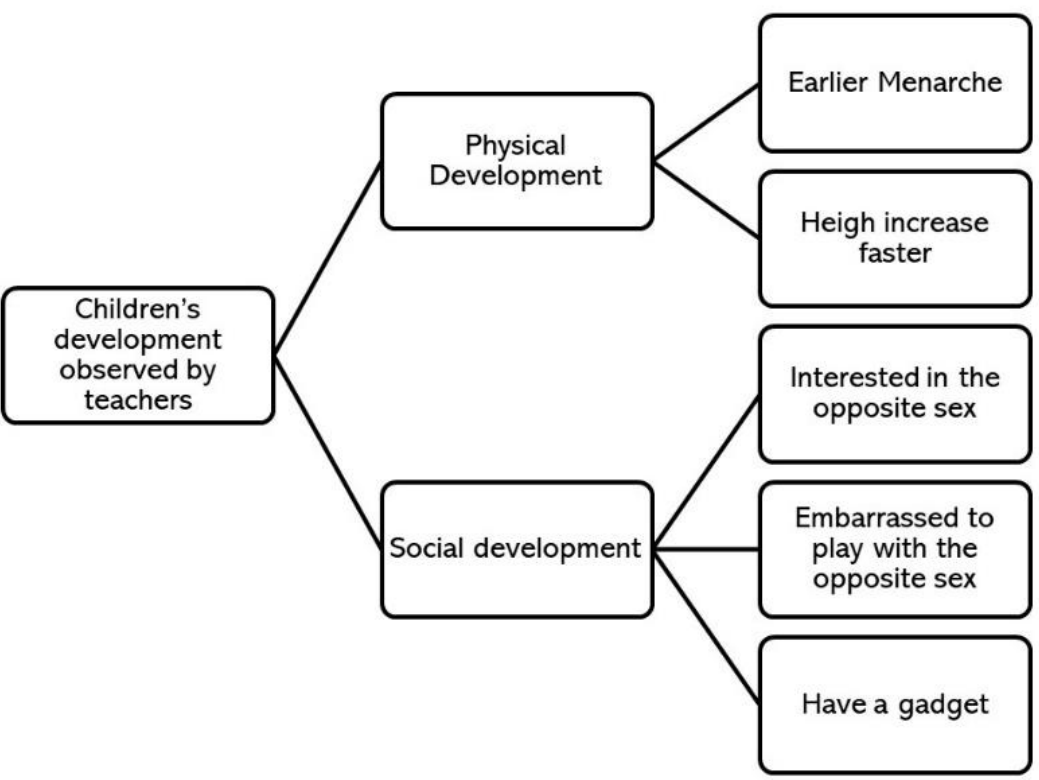

Figure 1. Children's development observed by teachers

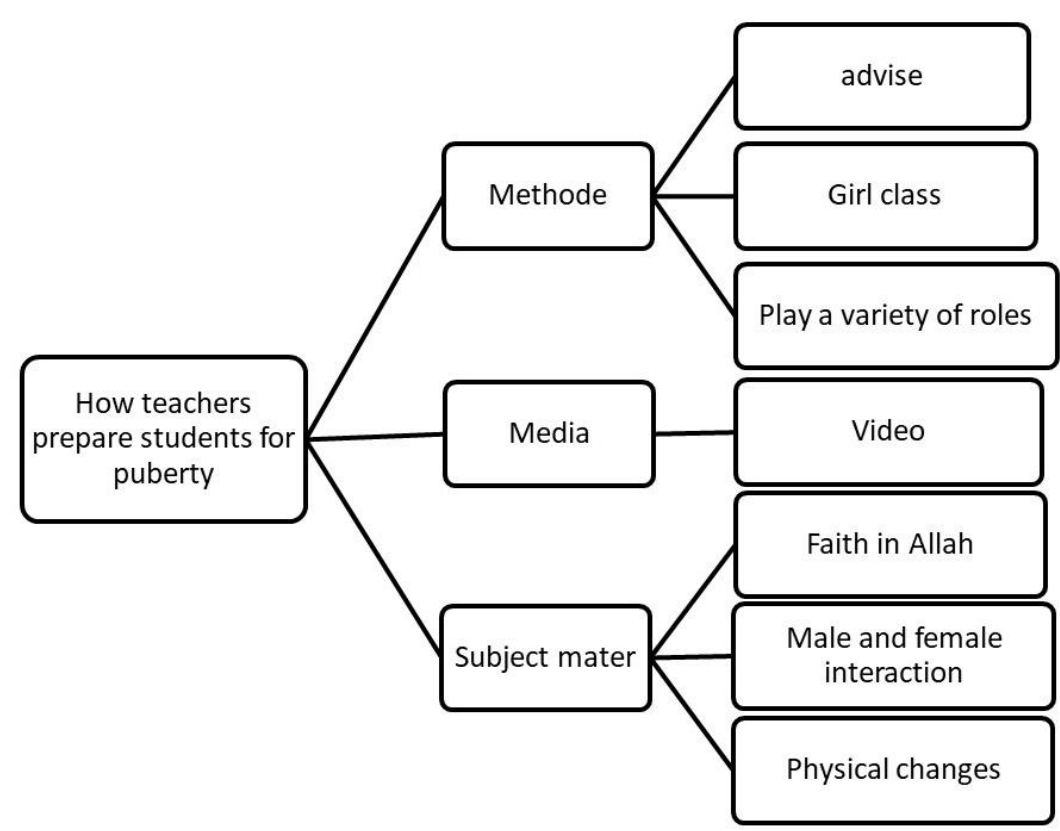

Figure 1. Teachers' preparation to face puberty 


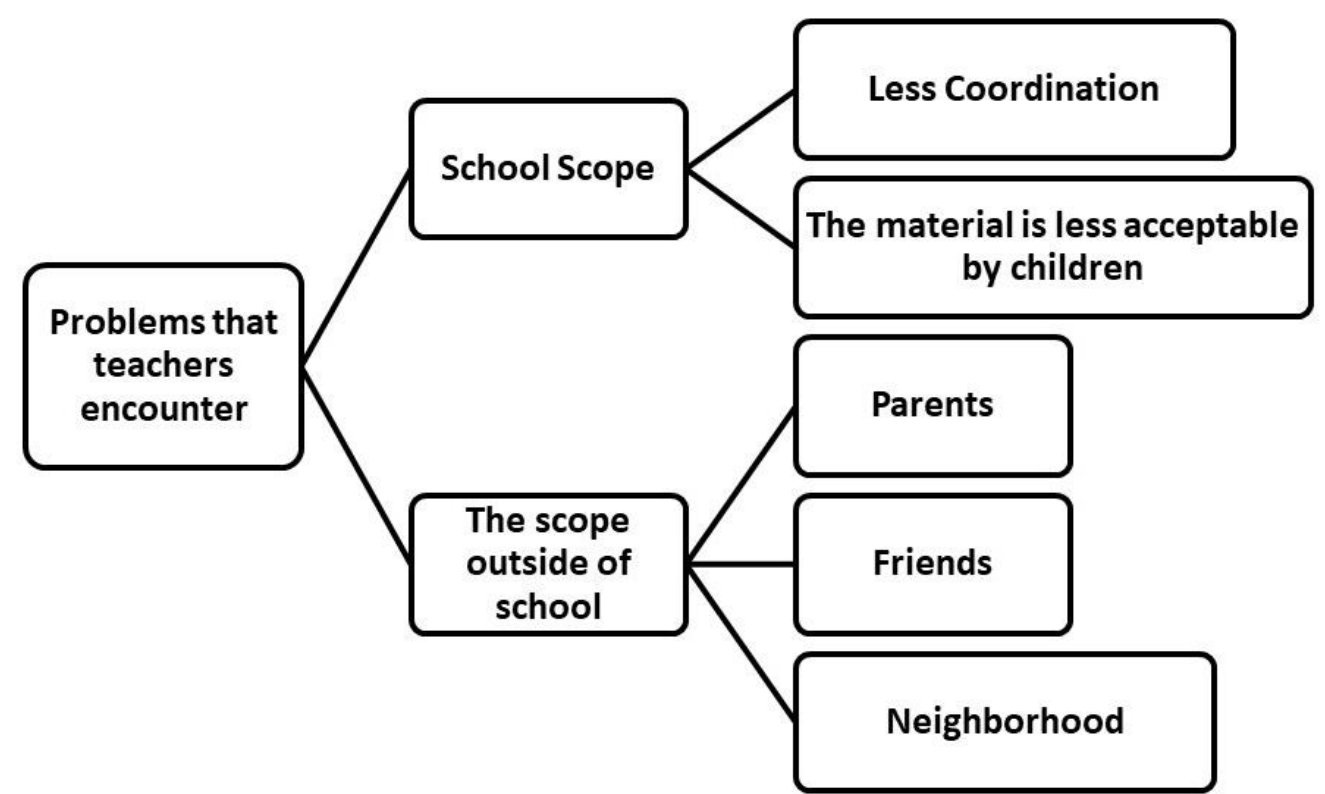

Figure 2. The problems encountered by teachers 